\title{
ПЕРЕКЛАДОЗНАВСТВО
}

UDC 81'25+(347.96:7.071.3)

DOI https://doi.org/10.32838/2710-4656/2021.2-2/02

Alexeyev N. E.

National University "Odessa Law Academy"

Alexeyeva L. I.

International Humanitarian University

Syniova T. $V$.

International Humanitarian University

\section{TRAINING TRANSLATORS AND INTERPRETERS IN UKRAINE: MODERN CHALLENGES}

Translation as a type of intellectual activity has a long history and there have been few periods having bigger effect on the practical work of translators than the late $20^{\text {th }}$ - early $21^{\text {st }}$ century. Numerous factors, ranging from socio-political to technological ones, result in drastic - often conflicting - changes both in the translation market and translation activity. This inevitably sets new tasks before the institutions training translators and interpreters.

The article investigates into the current issue of modern challenges facing translator and interpreter training (T\&I training) with special emphasis on the problems having arisen in the recent period due to modern socio-political developments, especially in the EU countries, the achievements of information technologies in the sphere of translation and findings of the relevant research.

High awareness of the problem among the European academic and scientific community resulting in the growing number of research into the matter in question testifies to the relevance of the topic of the study.

An attempt has been made to systematize and classify the above said problems involving the recent European research into the issue; the European statistics concerning T\&I training in the EU countries has been studied frequently revealing similar challenges facing $T \& I$ training systems both in European countries and Ukraine.

The origin of the current problems in training translators and interpreters has been investigated as well as the degree of their importance for different countries, particularly EU countries and Ukraine.

Specific features of the domestic system for training translators and interpreters have been identified; both positive and negative characteristics of the approaches existing in the national T\&I training system have been highlighted.

Division into strategic and tactical challenges for Ukrainian T\&I training system has been propounded according to the levels at which the problems at issue are to be addressed.

The strategic challenges facing Ukrainian system for training translators and interpreters have been analyzed; possible avenues for reaction thereto have been proposed and problematic issues for further research have been identified.

Key words: training translators and interpreters, T\&I training, strategic challenges for $T \& I$ training system, information technologies for T\&I training, translatology, translation market, domestic practice of T\&I training, teacher-centered training paradigm, academic accreditation systems for translators, European lingua franca.

Translation is justly ranked among the oldest types of human intellectual professional activities. Although its fundamental objective-that of promoting international communication - has been the same at all times, the urgent needs of the society vary in different periods under the influence of specific historical circumstances thus formulating particular tasks and requirements for translators. The new tasks, general situation and developments in the educational system, in turn, have placed new challenges before 
the institutions engaged in training translators and interpreters.

The recent 30 years' period has witnessed dramatic changes in many spheres of life, science and education, which have not bypassed translation as a field of knowledge, activity and as a profession resulting in intensive research causing emergence of new concepts and approaches. New goals and environment have inevitably modernized the standards for the professional translators thus setting new tasks before the educators in this field. In addition, new findings in translation study (hereinafter - TS) and research into the theory of translator and interpreter education (hereinafter T\&I) require their practical testing and application, which predetermines the relevance of this article.

This article aims at determining, studying and systematizing the challenges that T\&I training presently faces, with special emphasis placed on the situation in Ukrainian higher educational institutions. It further attempts to throw light on the conditions, which have resulted in the emergence of the challenges in question.

The subject of this paper is the modern state of T\&I training in Ukraine within the context of modern challenges to translator education in European (particularly EU) countries enrooted in the changes occurring on the international translations market, in educational, scientific and IT spheres.

The task of this paper is to develop and suggest possible reactions to these challenges and prospective avenues for the solution of some problems facing T\&I training system in Ukraine.

The material for this study includes EU countries' national reports on the translator training, European research in the field as well as domestic practice in training translators and interpreters at International Humanitarian University (Odessa) and National University "Odessa Academy of Law".

It should be specially noted that the interest in the matters of translator pedagogy has drastically increased within the recent two-three decades. The works have covered a vast array of issues developing both theoretic and practical approaches to the problems of T\&I training. This is especially true of European researchers who have addressed many problems having special topicality also for Ukrainian educators and researchers in the field in question. Hence, Donald Kiraly in his book "Pathways to Translation" formulates nine challenges to the development of modern paradigm of translator training practices:

Challenge 1: "the absence of a systematic approach to translation education based on both pedagogical and translation principles".
Challenge 2: "the failure of translation pedagogy to use relevant contributions from other disciplines (sociology, anthropology, cognitive science, and psychology) and research from modern translation studies as foundations for translator training".

Challenge 3: "a one-dimensional view of the process of translation, characterized by overdependence on the linguistic model of translation and a discounting of the social and cognitive realities of professional translation".

Challenge 4: "the failure to merge a grammatical model of translation teaching with the interpretive and cultural models of translation teaching."

Challenge 5: "a dependence on the teachercentered performance magistrale in the translation classroom".

Challenge 6: "an acceptance, and even encouragement, of a passive role for translation students".

Challenge 7: "a failure to undertake (and to apply the results of) empirical research on translation processes as a means to build a model of translation and translator competence upon which a translation pedagogy may be based".

Challenge 8: "an inability to distinguish the components of translator competence and to distinguish language-related competences shared with bilinguals from professional competences".

Challenge 9: "an absence of criticism of old practices and assumptions about curricula, including the usefulness, effectiveness, and teaching methods of certain specialized translator training, such as translation into the foreign language". [1]

It should be noted that this list of challenges unites both general and more specific problems, e.g. challenges 1,2 and 7 set fundamental tasks whereas points $3,4,8$ and 9 address narrower issues of teaching strategies and methods. In addition, points 5 and 6 appear to probe into two sides of one idea since the teacher-centered training paradigm obviously envisages a more passive role of the students.

Paradoxically, the wide search for new theoretical and practical approaches to training translators and interpreters and criticism of older theories and methods seem to produce more questions than answers. In 2005, Anthony Pym formulated ten more problems facing T\&I training calling them "recurrent naiveties" which haunt the training of translators [2], namely

\section{Training has to be in universities.}

It should be kept in mind that A. Pym strongly advocates the idea of effective T\&I training though specialized courses, mentoring, etc., which in fact, has been and often remains widely accepted European 
practice. History provides a domestic example of a very successful institution of this type popularly known as "Chkalov courses of foreign languages", which functioned in Odessa in the 1960s-1980s having among others the objective to fill the gap in the number of professional translators. Indeed, this idea closely merges with that of training professionals other than linguists in basics of tanslatology and practical methods of translation, which actually goes in line with the European practice where "firms and institutions increasingly employ graduates with a degree in technical subjects who also have excellent language skills rather than translators" [3].

2. Training has to cover everything that translators do.

"The programmes can be quite rich and diverse, offering training in computer skills, new technologies, business skills, a range of specialized translation areas, translation theory, perhaps translation history, and general humanistic courses available in the institutions. The ideal product of these programs would be a professional with a very rich skill set" [4].

This continues the argument of academic $v$. vocational ideologies of T\&I training. Explaining this statement John Kearns writes "It is often in universities' interests that certification and accreditation systems for translators be based on the kind of 'comprehensive' training programmes which they believe they can provide" [5]. The availability and competition between the two European systems of institutional translator training in Europe allows this discussion, unlike the situation in many Eastern European and ex-Soviet Union countries where T\&I training has been and still is traditionally the domain of universities with vocational T\&I training institutions remaining mostly undeveloped.

1. People should be trained to be just translators.

This prejudice is frequently based on the following misconceived idea that:

2. There is one huge job market for translators.

Indeed, many researchers capitalize on factors creating high demand for translation services. For example, the study of Universidad de Granada, (Granada, Spain) "Translator training and modern market demands" reads: "As international communication has grown, $\langle\ldots>$ the volume of documents to be translated in order to reach target groups beyond national borders has multiplied manifold. <..> The constant expansion of the European Union and the ensuing increase in the number of official languages (at present 20) - calls for consensus and adaptation of uniform guidelines, regulations, rules, etc. Globalisation and the so-called Euro Area are driving forces behind the increased demand for translations, as they promote international trade and tourism $\langle\ldots\rangle$ and international relationships in general. In order to face this variety of demands and to handle the support tools available to translators $\langle\ldots\rangle$ special attention is required in the training of future translators" [6].

Theoretically, with regard to the above said, a boom on the translation market should be anticipated; the situation, however, is far from being that straightway.

A more pessimistic viewpoint has it: "Is there a developed labour market for professional translators? Easy to check. Just keep track of how many full-time jobs are advertised for translators. In most countries you will soon start to wonder why anyone would want to be trained for a field with so few openings" [2].

New, frequently incidental and conflicting factors influence the situation on the market. On the one hand, the consolidation of European English as a European lingua franca [7] and the growing awareness of it practically in all European and many Asian countries decrease the demand fortranslation service in the sphere of international business and communication. The development and wide spread of efficient computer translation tools have the similar effect, which allows solving many translation tasks without involving professional translators. On the other hand, political considerations, in particular in EU, such as fear of language imperialism, result in production of many translations where there is actually no or little practical need. Paradoxically, the situation on the translation market does not have a direct effect on the availability of and demand for translator training since the number of students who actually find full-time jobs tends to be less than 30\% (in Spain, Germany and Italy, with numbers even lower reported for Hong Kong) [4]. Presumably the graduates find other jobs where their skills are an additional factor at best. Another consideration, as Anthony Pym has justly noted, may be that "In many cases youth unemployment has also played a role, creating student demand for vocationally oriented instruction programmes even in the absence of rising market demands for well-paid full-time translators and interpreters" [8]. A similar situation can be witnessed in Ukraine where even a lesser number of graduates qualified as translators find full-time jobs according to their qualification. The traditional way-out that the universities offer is the combination of language studies, translator training and pedagogical course with the prospect of future employment as language teachers or researchers. An additional strong incentive for Ukrainian students 
to take these courses at universities is the hope to improve their immigration prospects.

3. Trainees should all work into the same language.

A mixed group of translation students whose mother tongues are, for example, English and Spanish is undoubtedly a very promising option. This would seem a very far prospect for Ukraine unless the possibilities offered by distance training are employed. The latter solution definitely requires sizable organizational efforts but the result may pay manifold.

\section{Translation is not language learning}

A lot of effort has been made to discard the opposite idea - the one that a good command of a foreign language alone makes a good translator/interpreter. This misconception still persists although mostly as an unprofessional belief. It used to haunt most of T\&I training institutions not only in this country but also in Europe - the National Report on the training of translators and interpreters in Germany reads that there is "...the tendency to equate T\&I training with foreign language training or more general "language studies" and that "only recently have there been efforts to develop course components specific to translation and interpretation courses" [3]. However, the opposite approach can also be regarded harmful. Exclusion of translation tasks from the course of language studies, which is typical of the majority of modern educational aids, appears doubtful in terms of comprehension and effective assimilation of the material. Unfortunately, the methods, which were invented for the situation where English speaking teachers did not know the languages of their multinational class came to be regarded by many in the educator's community as a norm.

Further, proficiency in translation is impossible without deep linguistic knowledge although it is not limited thereto.

5. You translate, then you interpret.

Since translation is believed to be easier than interpreting the instruction commonly starts with translation. The idea to train students both in translation and interpretation simultaneously following the pattern "from simple to complex", which is advocated by the author, seems relevant and expedient.

8. Technology has changed nothing.

9. Technology is helping us.

The two opposing approaches are harmful at their extremes. Although statement 8 has practically lost support not only in academia but also among even the most conservative practitioners, little has changed in understanding of what and how should be taught in the sphere of IT technologies for translators in Ukraine. On the other hand, a number of courses, which has recently appeared in some European countries and nearly entirely concentrate on IT cannot be regarded as the sole source of T\&I training.

\section{Theories don't help trainees.}

Theory v. practice has been a long-standing argument in many spheres. Indeed, translation has been practiced for many thousands of years - most of the time with no or very little theory. The fact that the impact of theoretical knowledge on the quality of translation cannot be observed in direct ratio does not diminish the importance of theoretical study; moreover " $\ldots$ it is the theories themselves which need to be improved through being informed by professional knowledge so that they may be of better service to both trainers (even if this does mean challenging the institutional practices in which they work) and professionals" [5]. The correlation between theoretical and practical lessons is a methodological task within a curriculum.

The problems listed above are obviously characteristic not only of the European T\&I training system but also of the domestic one and they can be very approximately divided into "strategic" and "tactical" according to their present scale and importance.

For Ukraine the "strategic" challenges should include:

1. The solution of the dilemma: T\&I education v. T\&I training in the sense of which should prevail: university education or vocational training.

Historically, translators/interpreters have been almost entirely trained at universities both in the Soviet and post-Soviet periods, which was also characteristic of most eastern block countries. As Daniel Toudic (Université de Rennes) justly observed in the report "Translation and interpreting in central and Eastern Europe".

"It is a well recognised fact that some Central and Eastern European universities have a long tradition in the training of translators and interpreters. $<\ldots>$ translator and interpreter training for the national market was centrally regulated in quantity (number of graduates) and quality (selection of languages) to reflect the former needs" [3].

$\mathrm{He}$ further notes: "The significant imbalance between offer and demand, combined with the legal and social status of the profession itself, caused the national markets in these countries to be flooded by an influx of untrained lay "translators" and "interpreters" who discredited the profession by providing cheap and poor quality services" [3]. 
However, this can hardly be regarded as a result of deficiencies in university training; rather it should be viewed as an impact of the economic policy of shock therapy of the 1990s on the one hand, and little understanding of the specificities of translation by clients and their desire to pay minimum even at the expense of the quality, on the other hand. Lack of funding and associated with this drain of qualified specialists in the field of higher education are the constant problems for Ukrainian universities although they still remain the institutions capable of providing adequate T\&I training. The universities are no longer monopolists in language study since numerous commercial courses have filled nearly all niches in foreign language training. The employers readily accept international certificates that some organizations provide or rely on in-house interview where it concerns language proficiency. These employees would frequently have to do translation work although the abovementioned international examinations have nothing to do with translation. However, a university degree would be required for a full-time translator job. Reputable Ukrainian researchers and educators in the sphere of T\&I training G. Miram and A. Gon hold the opinion that the education of an interpreter/translator should consist of: "... fundamental university language course followed by a course in translation, five years of apprenticeship starting with easy standard written translations, then consecutive interpretation in pair with a more experienced colleague, try-outs in conference translation also under the guidance of an experienced interpreter who can always lend a hand and finally independent conference translation on a familiar topic in a well-disposed audience" [9].

This classical scheme causes little argument, except probably for the duration of the apprenticeship period; the only question is whether the translation course can be provided by an institution other than university. It seems to be possible and even desirable since such decentralized organizations may offer the possibility to choose between various approaches and tactics of training but they would still have to earn the employers' trust.

2. Development of evaluation criteria remain a pressing issue for T\&I training.

Anthony Pym emphasizes the opinion held be many researchers that "... evaluation will remain a problematic issue for as long as internal criteria ('accomplishment of learning aims') fail to connect with diversified professional practice" [4].

This issue can and probably should be regarded wider, in terms of developing both criteria for evaluation of the learning results and more generally the standards of the profession. The topicality of this problem in Europe is admitted at all levels in academic, official and professional organizations, e.g. the National Report on the training of translators and interpreters in Germany among major deficiencies in the system of T\&I training mentions "the lack of any official definition as to what qualifies a "translator" or "interpreter", adding that despite recent attempts to address the problem "there is no generally accepted, official qualification required for using the designation "translator" or "interpreter" [3]. Since this problem is similar in Europe and Ukraine, joint efforts in this directions appear expedient.

3. Since Ukrainian universities try to cover all eventualities in order to provide jobs for their graduates it is frequently hard to understand who they actually train: teachers, translators/interpreters, tourist agents or linguistic researchers.

This tendency is understandable and may even be justified. John Kearns mentions the same situation in Europe where in an attempt to improve employment prospects, the graduates trained as translators are sometimes referred to as "linguistic advisers", "linguistic mediators", and "cultural communicators" [5]. However, the desire to train a multifaceted specialist should not result in the mixture of courses. A distinctly independent T\&I course can become most effective as a Master course.

4. The influence of IT technology on translation in general and translator training can hardly be overestimated.

Kayoko Takeda remarks: “... translation memories, data-based machine translation and content management systems ... These technologies are having a profound impact on the way translators work, particularly in the localization industry" [10].

Despite the fact that almost everybody - practicing translators, educators and researchers in the sphere of translatology agree on the necessity to widely introduce courses of IT technologies into educational programs, very little practical output can be observed at Ukrainian universities so far. It seems that the process has been frozen at the stage of trial and errors.

The persistence with which the issue is raised, also in Europe, makes believe that either the importance and relevance of the problem has not been fully recognized or the ways and means (technical and methodological) have not been discovered and developed so far. For example, John Kearns in his $\mathrm{PhD}$ thesis "Curriculum Renewal in Translator Training: Vocational challenges in academic environments with reference to needs 
and situation analysis and skills transferability from the contemporary experience of Polish translator training culture" strongly criticized European Center for Modern Languages Report where the "influence of CAT software is only mentioned very cursorily. Nowhere is it suggested that translators need to be taught about the Internet as a resource and, while the report acknowledged that there were "questions [about] how training programmes should respond to new technological developments which impinge on the work of translators and interpreters" [11], nowhere does it make any attempt to identify what these questions are, much less to answer them" [5].

5. Educators in T\&I remain a challenge for Ukrainian universities.

There are only too many educators in the sphere of T\&I training who are actually foreign language teachers having little or no experience in professional translation. Researchers in TS (again not necessarily professional translators) comprise a smaller portion of the academic staff in this field. The latter commonly lecture on theoretical disciplines whereas the former conduct practical lessons. Since experience remains indispensable in T\&I training, like in many other spheres, the involvement of practical translators and interpreters in the educational process appear to be the best option. This can also assist in facing the next challenge:

6. Bringing training closer to the requirements of the market of translations.

This problem has always been characteristic of university education in general and T\&I training in particular. Moustafa Gabr focuses on the need to put knowledge into practice, instead of focusing only on theoretical contents, and the need to make students aware of how translation is practiced in 'the real world'. [12] However, quite a number of methods have been developed both in domestic and European practice in order to cure the deficiency. "Some of the steps being taken to bring training closer to the market include inviting professionals into the classroom, assessing of students on the basis of portfolios of their completed translations, using real-world ('authentic') translation tasks with explicit instructions from a client, and generally modelling competencies and skill sets in ways that can match up with market demands..." [8].

The Faculty of Translation and Interpreting at the University of Granada suggests an innovative teaching project named 'Aula.int, an online translation classroom' within the strategy of the Professional Approach to Translator Training aiming at "introducing translation students to the professional market and helping them get acquainted with working conditions in the real labour market by means of a simulated translation agency" [6].

However, in addition to "strategic" challenges to be coped with at a university or even ministerial levels there are various issues to be addressed at the level of a specialized university department or individual educator e.g. the teacher-centered (performance magistrale) model $\mathrm{v}$. alternative models or grammatical model of translation teaching v. interpretive and cultural models of translation teaching. These as well as some other issues remain debatable offering prospects for further research.

Summarizing, the following conclusions can be made:

- Rapid and drastic political, cultural and technological changes of the recent three decades predetermine new challenges for the translator profession, which formulate new requirements for T\&I training and relevant problems for the researchers;

- These challenges are basically similar for European countries and Ukraine although the degree of their importance vary;

- The problems facing T\&I training can be classified into "strategic" and "tactical", the former to be decided at the ministerial or university level whereas the latter remain the domain of specialized departments as well as individual researchers and teachers;

- Among the most acute "strategic" problems the following should be mentioned: application of IT technologies in T\&I training, which requires additional theoretical development and methodological support; and training of educators in T\&I.

\section{References:}

1. Kiraly D. Pathways to Translation: Pedagogy and Process. (Translation Studies 3). Kent, Ohio \& London England : Kent State University Press. 1995. URL: https://ru.scribd.com/document/288572257/Donald-C-KiralyPathways-to-Translation-Pedagogy-and-Process-Translation-Studies-1995-pdf

2. Pym A. "Training Translators: Ten Recurrent Naiveties." Translating Today 2, January 2005. 1-5. URL: https://www.researchgate.net/profile/Anthony-Pym-3/publication/267371008_Training_translators_-_ten_ recurrent_naiveties

3. National Reports on the Training of Translators and Interpreters Appendix to the Final Report. URL: http://www.celelc.org/projects/Past_Projects/TNP_Languages/TNP1_resources/SP7NatReps.pdf 
4. Pym A. "Translator training.” 2009. URL: https://www.researchgate.net/publication/297128820_Training Translators

5. Kearns J. Curriculum Renewal in Translator Training: Vocational challenges in academic environments with reference to needs and situation analysis and skills transferability from the contemporary experience of Polish translator training culture. Thesis submitted for the award of PhD in Applied Language Studies. 2006. URL: https://core.ac.uk/download/pdf/11311302.pdf

6. Translator training and modern market demands, Aula.int1, Perspectives: Studies in Translatology. 2005. Universidad de Granada, Granada, Spain. Vol. 13. №2.URL:https://www.researchgate.net/publication/261588094 TRANSLATOR_TRAINING_AND_MODERN_MARKET_DEMANDS

7. Alexeyev N. E., Alexeyeva L. I., Sinyova T. V. Euro-English: peculiarities of evolution. Науковий вісник Міжнародного гуманітарного університету. 2018. Випуск 33 T. 2. C. 162-166. URL: http://www.vestnikphilology.mgu.od.ua/archive/v33/part_2/Filologi33_2.pdf

8. Pym A. "On the Market as a Factor in the Training of Translators." Koine 3. 109-121. 1993. URL: https://usuaris.tinet.cat/apym/on-line/translation/market.html

9. Мирам Г., Гон А. Профессиональный перевод. Киев : Эльга, Ника-Центр, 2003. 136 с.

10. Kayoko T. What interpreting teachers can learn from students: A case study Monterey Institute of International Studies. URL: http://trans-int.org/index.php/transint/article/viewFile/88/67

11. European Centre for Modern Languages. Report: Workshop No. 7/2000. project 2.6.1. 'Development of Curricula and Methodology for Translation and Interpreting Courses'. 2000. December. URL: http://archive.ecml. at/documents/reports/wsrep261E20007final.pdf

12. Gabr M. "Program Evaluation: A Missing Critical Link in Translator Training." Translation Journal 5:1, January 2001. URL: https://translationjournal.net/journal/16edu.htm

\section{Алєкссєв М. Є., Алєксєва Л. І., Синьова Т. В. ПІДГОТОВКА УСНИХ ТА ПИСЬМОВИХ ПЕРЕКЛАДАЧІВ В УКРАЇНІ: СУЧАСНІ ВИКЛИКИ}

Переклад як вид інтелектуальної діяльності має свою давню історію, і було небагато періодів, які мали більший вплив на практичну роботу перекладачів, ніж кінець 20 - початок 21 століття. Численні фактори, починаючи від сочіально-політичних і закінчуючи технологічними, призводять до різких, часто суперечливих змін як на ринку перекладів, так і на перекладацькій діяльності. Це неминуче ставить нові завдання перед установами, які готують перекладачів.

У статті досліджено актуальну проблему сучасних викликів, що постали у сфері підготовки усних та письмових перекладачів, з особливим акцентом на проблеми, які виникли в останній час унаслідок сучасних сочіально-політичних подій, особливо в краӥнах $Є С$, досягнень інформаційних технологій у сфері перекладу і також висновків відповідних досліджень.

Висока заиікавленість проблемою серед європейської академічної та наукової спільноти, що призвела до зростання кількості досліджень з даного питання, свідчить про актуальність теми дослідження.

Було зроблено спробу систематизувати та класифікувати вищезазначені проблеми з урахуванням останніх європейських досліджень иієї теми; було вивчено європейську статистику щодо підготовки перекладачів у краӥнах $C С$, часто виявляючи подібні виклики, що стоять перед системами підготовки перекладачів як у європейських краӥнах, так і в Украӥні в тому числі.

Досліджено походження новітніх проблем у сфері підготовки перекладачів, а також ступінь їх важливості для різних краӥн, зокрема краӥн СС та України.

Визначено особливості вітчизняної системи підготовки перекладачів; висвітлено як позитивні, так і негативні характеристики підходів, що існують у національній системі підготовки перекладачів.

Було запропоновано поділ на стратегічні та тактичні виклики для української системи підготовки перекладачів, виходячи з рівнів, на яких мають розглядатися відповідні проблеми.

Проаналізовано стратегічні виклики, які стоять перед украӥнською системою підготовки перекладачів; запропоновано можливі шляхи реакиії на них та визначено проблемні питання для подальших досліджень.

Ключові слова: підготовка перекладачів, стратегічні виклики системі підготовки перекладачів, інформачійні технології в підготовиі перекладачів, перекладознавство, ринок перекладів, вітчизняна практика підготовки перекладачів, парадигма навчання, орієнтована на викладача, системи академічної акредитаиії перекладачів, Свропейська лінгва франка. 